\title{
Influence of edaphic and management factors on soils aggregates stability under no-tillage in Mollisols and Vertisols of the Pampa Region, Argentina
}

\author{
Filipe Behrends Kraemer ${ }^{\mathrm{a}, \mathrm{b}, \mathrm{c}, \star}$, Héctor Morrás ${ }^{\mathrm{b}}$, Patricia Lilia Fernández ${ }^{\mathrm{c}, \mathrm{d}}$, Matías Duval ${ }^{\mathrm{f}}$, \\ Juan Galantini ${ }^{\text {e,f }}$, Lucas Garibaldi ${ }^{\text {g,h }}$ \\ ${ }^{a}$ Cátedra de Manejo y Conservación de Suelos, Facultad de Agronomía, Universidad de Buenos Aires, Argentina \\ ${ }^{\mathrm{b}}$ Instituto de Suelos-CIRN-INTA, Argentina \\ ${ }^{\mathrm{c}}$ CONICET, Argentina \\ ${ }^{\mathrm{d}}$ Cátedra de Fertilidad y Fertilizantes, Facultad de Agronomía, Universidad de Buenos Aires, Argentina \\ ${ }^{\text {e }}$ Comisión de investigaciones científicas (CIC), Argentina \\ ${ }^{\mathrm{f}}$ CERZOS-CONICET, Dpto. Agronomía-Universidad Nacional del Sur, Bahía Blanca, Argentina \\ ${ }^{g}$ Universidad Nacional de Río Negro. Instituto de Investigaciones en Recursos Naturales, Agroecología y Desarrollo Rural. Río Negro. Argentina \\ ${ }^{\mathrm{h}}$ CONICET. Instituto de Investigaciones en Recursos Naturales, Agroecología y Desarrollo Rural. Río Negro. Argentina
}

\section{A R T I C L E I N F O}

\section{Keywords:}

Aggregates stability

Organic carbon fractions

Le Bissonnais tests

Cropping intensity

Soil classification (soil taxonomy): Mollisols

and Vertisol

\begin{abstract}
A B S T R A C T
In the highly fertile and productive soils of the Pampa Region of Argentina, constraints on soil water regime as a consequence of the decline in aggregates stability and the development of platy structures, are observed. Most of agricultural plots in this region, even under no tillage, are subjected to simplification of crop sequences (low cropping intensity) with predominance of soybean. On the contrary, some farmers are intensifying the crops sequence to avoid soil degradation and equilibrate economical incomes. The aim of this work was to evaluate the effects of intrinsic soil factors and of cropping intensity on aggregates stability in the surface horizon of the main soils in this region. Three Mollisols (an Entic Haplustoll and two Typic Argiudolls) and a Vertisol (Hapludert) located across a west-east transect in the northern part of the Argentinean Pampas were selected for this study. In each site two management treatments under no-till (GAP: Good Agricultural Practices -high cropping intensityand PAP: Poor Agricultural Practices -low cropping intensity-) and a soil without cultivation as a reference (NE: Natural Environment) were compared. In each treatment, aggregates destruction mechanisms were assessed by Le Bissonnais (1996) tests: slaking, microcraking and cohesion loss. Mollisols showed higher aggregates stability than the Vertisol. Differences on aggregates stability depended on management variables and on organic carbon contents in the Mollisols and on both clay content-clay type in the Vertisol, revealing a strong relationship of aggregation mechanisms with soils taxonomic order. In the Mollisols, the labile coarse particulate organic carbon fraction (POCc) determined the shifts on slaking and overall aggregates stability rather than other carbon fractions. In the soils studied, aggregates stability was linked mainly to management variables, best reflected by the cropping intensity index (CI). More intensive agricultural managements (GAP treatments) in Mollisols and Vertisol, resulted in an enhancement of aggregates stability; however, this relationship was stronger in the Mollisols. Surface horizons from both soil orders evidenced a high soil fragility related to slaking process $\left(\mathrm{FW}_{10 \mathrm{~s}}\right.$ and FW tests). Thus, FW test was the best test to discriminate between management treatments. The results obtained in this work allow, on the one hand, to understand the stabilization mechanisms of the structure in the surface horizon of the main Pampas soils and, on the other hand, to highlight the effect of different NT management practice on soil aggregate stability, which highly affects soil health and the sustainability of agricultural systems.
\end{abstract}

\footnotetext{
* Corresponding author at: A.P. Carranza 2722, 3 Depto, Ciudad Autónoma de Buenos Aires, CP. 1417, Argentina.

E-mail addresses: filipebk@agro.uba.ar (F. Behrends Kraemer), morras.hector@inta.gob.ar (H. Morrás), fpl@agro.uba.ar (P.L. Fernández), mduval@criba.edu.ar (M. Duval), jgalanti@criba.edu.ar (J. Galantini), lgaribaldi@unrn.edu.ar (L. Garibaldi).
} 


\section{Introduction}

No tillage cultivation (NT) is considered as one of the most successful soil management practices to promote soil conservation and for recovering degraded agricultural soils (Morrás et al., 2001; Derpsch et al., 2010). Among the benefits of this management are mentioned the increase in aggregates stability (Six and Paustian, 2014), organic matter (Six et al., 2004) and biological activity and a better erosion control (Derpsch et al., 2010). The humid Argentine Pampa is one of the largest areas dedicated to cereal and oil crops in the southern hemisphere, due to a temperate climate, adequate rainfall and soils with high productivity (Durán et al., 2011; Rimski-Korsakov et al., 2015). In this region, NT has been increasingly adopted during the last 30 years, already reaching almost $93 \%$ of cultivated lands (Nocelli Pac, 2018).

Despite the high natural chemical fertility of these soils, their high silt content, usually reaching $60-70 \%$ in the A horizon, is the cause of a low structural stability that favors a rapid deterioration of their hydrophysical properties when they are tilled. Also, the high proportion of fragile biolyths and volcanic glasses in their silt fraction seems to cause negative effects on its tensile strength and therefore on structural stability (Pecorari et al., 1990; Taboada et al., 2008). Moreover, along the last decades, and together with NT adoption, large changes have taken place in crops sequence composition, leading to the disappearance of pastures and the rapid expansion of soybean monoculture, resulting in long periods with bare soils (Novelli et al., 2011; Behrends Kraemer et al., 2013; Wingeyer et al., 2015). For instance, in the winter 2015 almost $90 \%$ of the crop area was under fallow (Pinto et al., 2017), evidently differing from crop diversification and high soil cover percentage recommended for NT management (FAO, 2013). Thus, and despite the expansion of NT, no clear improvements have been observed in soils organic matter content and features of physical degradation as platy structures and soil compaction have appeared and spread all over the region (Bonel et al., 2005; Morrás et al., 2012; Álvarez et al., 2014; Sasal et al., 2017; Behrends Kraemer et al., 2017, 2019). According to the concept of NT system and its assessment as proposed by Derpsch et al. (2014), this label may not be applicable to most of no-tilled agricultural lands in this region.

However, and following technical recommendations, an increasing proportion of farmers in the region are diversifying the crops sequence and increasing the time with soils covered by cultivated plants (Caviglia and Andrade, 2010). This improvement can be assessed by the cropping intensity (CI) index, which is defined as the length of the period with actively growing (green) crops in a sequence, on a yearly-basis (Caviglia and Andrade, 2010). In the Pampa region, the implementation of high CI under NT has shown increases in organic carbon content (Duval et al., 2013; Studdert and Echeverría, 2000), increases in the number and diversity of soil macro and mesofauna (Morrás et al., 2001; Bedano and Dominguez, 2016) a lower presence of laminar structure and of runoff events (Sasal et al., 2017) and increases in aggregates stability (Novelli et al., 2013).

Aggregates stability is a key parameters for assessing structural deterioration because it depends on complex interactions between soil management strategies, soil properties and plant roots traits (Garcia et al., 2019) and have been linked to agricultural yield, water dynamics and soil fauna (Hermawan and Cameron, 1993). Physical soil health is strongly related to aggregates stability which governs some other physical properties (i.e. pore configuration and stability, infiltration, drainage, water retention); therefore, the loss of aggregates stability is the first step for several degradation processes (i.e. soil crusting, compaction, erosion) (Denef et al., 2002; Aparicio and Costa, 2007). Among soil properties, soil organic matter is one of the main factors promoting soil aggregates stability (Tisdall and Oades, 1982; Six and Paustian, 2014). Numerous authors have suggested that the aggregates stability dynamics may be described better soil organic carbon (SOC) quality and particularly by its labile fractions, than by SOC quantity (Capriel et al., 1990; Albrecht et al., 1992; Le Bissonnais, 1996).
However, in the Pampa region, the effects of CI on aggregates stability is complex and not well understood as it not only depends of crop management, but on soil type and organic matter quality as well (Novelli et al., 2013; Behrends Kraemer et al., 2019). As other soil quality indicators, the study of soil aggregates stability needs the elucidation of the differential effects of intrinsic and dynamics factors. Intrinsic factors (i.e. soil texture, clay mineralogy) are determined by basic soil factors and soil formation processes (Karlen et al., 2003). Clay mineralogy, calcium and iron content are reported to affect aggregates stability, although with different impact according to soil type (Le Bissonnais, 1996; Cañasveras et al., 2010; Igwe et al., 1999; Denef and Six, 2005). On the contrary, dynamic factors refer to soil properties closely linked to agricultural management (tillage, crops sequence, irrigation). For instance, in some soils, aggregates stability was found to increase with CI, which was related to changes in organic matter (Novelli et al., 2013; Sasal et al., 2017) and with increases in sub-critical hydrophobicity (Behrends Kraemer et al., 2019). Even when aggregates stability is considered as a suitable soil quality indicator, studies assessing this parameter in contrasting CI managements under NT are still scarce. Moreover, few studies have dealt with aggregation mechanisms in soils with contrasting mineralogy and under different $\mathrm{CI}$ in this region.

Mechanisms involved in aggregates destruction as slaking, microcraking and loss of cohesion, can be discriminated by Le Bissonnais (1996) method by fast wetting, slow wetting and stir after ethanol prewetting test, respectively. Fast wetting and subsequent slaking is reported as one of the main mechanisms of the low aggregates stability in this region (Novelli et al., 2013; Restovich et al., 2012). Lado et al. (2004) and Vermang (2012) stated that fast wetting and subsequent slaking is related to soil moisture, which depends on crops residue characteristics. Therefore, it may be hypothesized that crops sequence with low CI, thus with low vegetation cover and low stubble content, will lead to lower soil moisture status by increasing water evaporation and runoff, and therefore aggregates would slake faster when subjected to heavy rainfall. Moderate to high rainfall erosivity are described in this region (300-600 MJ ha ${ }^{-1} \mathrm{~h}^{-1}$ year $^{-1}$ ) (Behrends Kraemer et al., 2018; Rojas and Conde, 1985). This effect would be enhanced by high soil silt content, with which formation and stabilization of structure is weak (Wischmeier et al., 1971; Álvarez et al., 2014; Pecorari et al., 1990) and highly dependent on biological aggregation mechanisms (Oades, 1993). However, this mechanism is also mediated by clay minerals typology, whose differential behavior would be evidenced by slow wetting tests.

Particularly in the Pampean Region, organic matter and silt content, together with clay content and mineralogy (illites vs. smectites) are considered to be the main factors determining aggregates stability. In this sense, the importance of organic matter as the primary binding agent for soil aggregates holds true for moderately weathered soils dominated by illitic clay minerals as in Mollisols (Denef et al., 2002). However, in Vertisols, with high content of smectites, the effects of organic matter and drying-wetting cycles on aggregates stability are still unclear, because they can increase or decrease aggregation (Denef et al., 2002). In short, the suitability of aggregates stability tests and the mechanisms involved could be more precisely assessed considering both intrinsic soil characteristics and management factors.

Thus, the objective of this study was to evaluate the role of dynamic and intrinsic factors and particularly the effect of different cropping intensities in soils under NT on aggregates stability of Mollisols and Vertisols from the Pampean region

\section{Material and methods}

\subsection{Soils and management}

For this study, representative soils and agricultural managements of the Pampa region were selected by scientists and farmers participants of the BIOSPAS consortium, an interdisciplinary project, whose long-term goal is to define ecological indicators of sustainability under no-till 
farming in Argentina (Wall, 2011). Two approaches were followed to evaluate the effects of agricultural management on aggregates stability. The first one was an integrative and comparative evaluation of agricultural plots under NT with either high or low CI. Thus, two agricultural managements were identified: Good and Poor Agricultural Practices (GAP and PAP). The second was a mechanistic approach that analyzed management variables regardless of the main treatment allocation (GAP or PAP).

Because of the difficulty in establishing strict replication of management practices in actual production fields, the criteria described by the program of Certification in Good Agricultural Practices of AAPRESID (http://www.aapresid.org.ar/ac/buenas-practicas-agricolas/, last visited August 11, 2013) and the guidelines of Good Agricultural Practices developed by the Food and Agricultural Organization of the United Nations (www.fao.org/prods/GAP/index_en.htm, last visited August 11, 2013) were adopted to allocate both managements. Thus, GAP are sustainable agriculture managements under NT with intensive crop rotations $(\mathrm{CI}>0.6)$, nutrient reposition and minimum use of agrochemicals (herbicides, pest control) and PAP are unsustainable agriculture managements under NT with crop sequences closes to monocultures (CI $<0.5$ ) with low nutrient reposition and high use of agrochemicals (Table 1). In addition, in each site, a reference soil (NE: natural environment) was evaluated; this was the same or a similar soil with natural vegetation $(\mathrm{CI}=1)$ located nearby the agriculture treatments (closest than $5 \mathrm{~km}$ ), where no agriculture was performed at least for 30 years.

To differentiate between the two contrasting managements (GAP and PAP) several variables were considered (Table 1): a) Cropping intensity $\left(\mathrm{CI}_{\mathrm{agr}}\right)$ that refers to the length of the period with actively growing crops in a sequence, on a yearly-basis (Caviglia and Andrade, 2010). For NE, $\mathrm{CI}$ was noted as $1\left(\mathrm{CI}_{\mathrm{all}}\right)$; b) Years under No-Till; c) Soybean/Crops: ratio of the number of total soybean crops and total crops; d) Maize/Crops: ratio of the number of total maize crops and total crops; e) Soybean/Maize: ratio between number of soybean crops and maize crops; $f$ ) Soybean only crop: number of years of soybean as only crop in the agriculture sequence (further information about soil management could be found in Figuerola et al. (2012); Rosa et al. (2014) and Behrends Kraemer et al. (2017, 2019). Also, from these variables a new index (PC1_management) with a principal component analyses was constructed, to synthetize management characteristics of the agricultural plots (PC1 $=78 \%$; principal autovectors: Soybean/Crops: 0.45 , Soybean only crop: variability: $0.45, \mathrm{CI}_{\mathrm{agr}}$ : -0.42 )

To evaluate the effects of soils type on aggregates stability, management treatments were replicated in 4 sites located across a west-east transect in the northern part of the Argentinean Pampas: 1) sandy loam

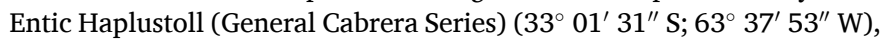
2) silty loam Typic Argiudoll (Monte Buey Series) ( $32^{\circ} 58^{\prime} 14^{\prime \prime} S ; 62^{\circ} 27^{\prime}$

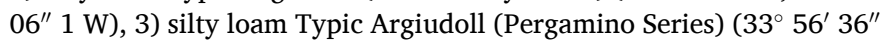
$\mathrm{S} ; 60^{\circ} 33^{\prime} 57^{\prime \prime} \mathrm{W}$ ) and 4) silty clay loam Hapludert (Santiago Series) (31 ${ }^{\circ}$ $52^{\prime} 59,6^{\prime \prime} \mathrm{S} ; 59^{\circ} 40^{\prime} 07^{\prime \prime} \mathrm{W}$ ). The first three soils are Mollisols with high silt content and fine sands together with clay mineralogy in the topsoil consisting of 2:1 clays, mainly illites with a small proportion of irregular interstratified illite-smectite minerals, and traces of kaolinite. Contrarily, the Hapludert presents higher clay content with a considerable proportion of smectite together with lower proportions of the previously mentioned clay minerals (Behrends Kraemer et al., 2012). The smectite plus I-S interstratified clay minerals content in the A horizon of each soil is presented in Supplementary Table 1. Former studies showed that physical, chemical and biological soil variables used to discriminate management treatments (NE, GAP and PAP) display different behavior between Mollisols and Vertisols (Calderoli et al., 2017; Behrends Kraemer et al., 2017, 2019). Thus, in this work the selected soils were discriminated in two groups according to their taxonomy at the order level.

\subsection{Soil characterization}

Bulk soil samples were collected in each experimental unit $(n=3)$ at $0-0.15 \mathrm{~m}$ depth. In crushed and $2 \mathrm{~mm}$ sieved soil samples, the following parameters were determined: Particle size distribution by the Robinson's pipette method for the clay $(<2 \mu \mathrm{m})$ and silt fractions $(2-50 \mu \mathrm{m})$ and by sieving for the sand fractions $(>50 \mu \mathrm{m}$ ) (Soil Conservation Service, 1972); Particle density with the pycnometer method (Blake and Hartge, 1986) with kerosene as non-polar liquid; Liquid limit (Ll) and Plastic limit (Pl) of Atterbergs method; Plasticity index (Pi) (Means and Parcher, 1965), Clay activity (CA) (Pl/ \% clay content); pH (1:2.5 soil: water) using a potentiometer; Electric conductivity (EC) using a

Table 1

Management characteristics for Good and Poor Agricultural Practices (GAP and PAP, respectively) for each soil during the 2004-2010 period.

\begin{tabular}{|c|c|c|c|c|c|c|c|c|}
\hline \multirow{3}{*}{ Soil treatment/ } & \multirow{2}{*}{\multicolumn{2}{|c|}{$\begin{array}{l}\text { Haplustoll (General Cabrera } \\
\text { series) } \\
\text { Mollisols }\end{array}$}} & \multicolumn{2}{|c|}{ Argiudoll (Monte Buey series) } & \multicolumn{2}{|c|}{$\begin{array}{l}\text { Argiudoll (Pergamino } \\
\text { series) }\end{array}$} & \multirow{2}{*}{\multicolumn{2}{|c|}{$\begin{array}{l}\text { Hapludert (Santiago series) } \\
\text { Vertisol }\end{array}$}} \\
\hline & & & & & & & & \\
\hline & GAP & PAP & GAP & PAP & GAP & PAP & GAP & PAP \\
\hline $2004 / 2005$ & $\begin{array}{l}\text { Wheat/ } \\
\text { Soybean }\end{array}$ & Peanut & Wheat/Sorghum & Soybean & Soybean & Soybean & Wheat/Soybean & Maize \\
\hline $2005 / 2006$ & Maize & $\begin{array}{l}\text { Wheat/ } \\
\text { Soybean }\end{array}$ & Maize & $\begin{array}{l}\text { Wheat/ } \\
\text { Soybean }\end{array}$ & $\begin{array}{l}\text { Wheat/ } \\
\text { Soybean }\end{array}$ & Soybean & $\begin{array}{l}\text { Sweet clover+Rye-Grass/ } \\
\text { Maize }\end{array}$ & Soybean \\
\hline $2006 / 2007$ & $\begin{array}{l}\text { Wheat/ } \\
\text { Soybean }\end{array}$ & Soybean & Wheat/Soybean & Maize & Maize & Soybean & Soybean & $\begin{array}{l}\text { Wheat/ } \\
\text { Soybean }\end{array}$ \\
\hline $2007 / 2008$ & Vetch/Maize & $\begin{array}{l}\text { Wheat/ } \\
\text { Soybean }\end{array}$ & $\begin{array}{l}\text { Vetch/Maize- } \\
\text { Soybean }\end{array}$ & Soybean & Soybean & Soybean & Wheat/Soybean & Maize \\
\hline $2008 / 2009$ & $\begin{array}{l}\text { Wheat/ } \\
\text { Soybean }\end{array}$ & Soybean & Maize & Soybean & $\begin{array}{l}\text { Wheat/ } \\
\text { Soybean }\end{array}$ & Soybean & Maize & Soybean \\
\hline $2009 / 2010$ & Soybean & Soybean & Wheat/Soybean & Soybean & Maize & Soybean & Soybean & Soybean \\
\hline $\mathrm{CI}_{\mathrm{agr}}^{\mathrm{a}}$ & 0.67 & 0.53 & 0.64 & 0.49 & 0.56 & 0.42 & 0.59 & 0.50 \\
\hline Years under No-Till & 13 & 5 & 28 & 10 & 6 & 5 & 13 & 9 \\
\hline Soybean/Crops ratio ${ }^{\mathrm{b}}$ & 0.40 & 0.62 & 0.28 & 0.75 & 0.50 & 1.00 & 0.44 & 0.57 \\
\hline Maize/Crops ratio ${ }^{\mathrm{b}}$ & 0.20 & 0.00 & 0.30 & 0.14 & 0.25 & 0.00 & 0.22 & 0.28 \\
\hline Soybean/Maize & 4 & 5 & 1 & 5 & 2 & 6 & 2 & 2 \\
\hline $\begin{array}{l}\text { Soybean as only crop } \\
(\%)^{\mathrm{d}}\end{array}$ & 0.17 & 0.50 & 0.00 & 0.66 & 0.33 & 1.00 & 0.33 & 0.50 \\
\hline
\end{tabular}

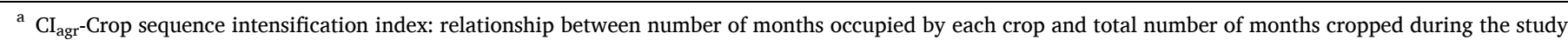
period.

b Number of soybean or maize crops in relation to total crops during the study period.

c Number of soybean crops related to maize crops (soybean/maize).

d Number of soybean as the only crop in the year. 
conductimeter; Exchangeable ions and cation exchange capacity (CEC) were determined by the ammonium acetate $1 \mathrm{~N}$ method and exchangeable cations were measured by atomic absorption spectrometry; Clay mineralogy (homoionic to $\mathrm{Mg}^{2+}$ ) was established by X-ray diffraction (Philips PW1050 with a $\theta / 2 \theta$ goniometer set to $50 \mathrm{kV}$ and 40 $\mathrm{mA}, 3-70^{\circ} 2 \theta$, step $0.02^{\circ}$ ) and a semiquantitative analysis was performed to determine smectite and smectite plus random interstratified illite/smectite proportions (S + I/S) (Holtzapffel, 1985).

\subsection{Aggregates structural stability tests}

Le Bissonnais methodology (ISO 10930:2012) (Le Bissonnais, 1996) was employed to assess soil aggregates stability. This procedure not only provides an overall status of aggregates stability but also allows distinguishing the different soil structural stability mechanisms regarding formation and maintenance of structure in different soil types.

Three undisturbed samples cores $\left(\sim 3300 \mathrm{~cm}^{3}\right)$ were taken from the topsoil $(0.15 \mathrm{~m})$ in each subplot (n:9 for each experimental unit) with a total of 432 samples for the whole experiment ( 3 samples per subplot $x 3$ subplots x 3 management treatments $\mathrm{x} 4$ soil types $\mathrm{x} 4$ tests). Sampling was done in winter at least two months after summer crops harvesting and before seeding to minimize both effects on soil structure.

Soil aggregates of about $3-5 \mathrm{~mm}$ were retrieved by manual disaggregation from undisturbed soil samples conserved at near field capacity. Then, samples were dried at $40{ }^{\circ} \mathrm{C}$ for $24 \mathrm{~h}$ and subdivided in $6 \mathrm{~g}$ subsamples to which the different stability tests were applied. Triplicate samples were subjected to four pre-treatments: a) fast wetting in distilled water (FW); b) stir agitation in distilled water of samples previously immersed in ethanol (Stir); c) slow wetting in distilled water. Samples were placed in a sponge holder subjected to $-3 \mathrm{kPa}$ column (SW). Also, a forth pre-treatment (d) was established in order to capture the early behavior of aggregates slaking. This pre-treatment is the same as the fast pre-treatment but the immersion time was change from 10 min to $10 \mathrm{~s}\left(\mathrm{FW}_{10 \mathrm{~s}}\right)$ (Behrends Kraemer et al., 2012). In addition, the average of a, b and c, was used (AS Mean) (Le Bissonnais and Arrouays, 1997; Chenu et al., 2000).

Aggregates were then sieved with a $0.05 \mathrm{~mm}$-mesh sieve while immersed in ethanol with a Feodoroff shaker. The aggregates retained were oven-dried at $40{ }^{\circ} \mathrm{C}$ for $48 \mathrm{~h}$. Then, they were air-sieved through a column of sieves to obtain the size distribution of dried aggregates: $>2$ $\mathrm{mm}, 2-1 \mathrm{~mm}, 1-0.5 \mathrm{~mm}, 0.5-0.2 \mathrm{~mm}, 0.2-0.1 \mathrm{~mm}$ and $0.1-0.05 \mathrm{~mm}$ and $<0,05 \mathrm{~mm}$. Results were expressed as mean weight diameter (MWD). Aggregates stability classes were: MWD $<0.4=$ very unstable, $0.4-0.8=$ unstable, $0.8-1.3=$ medium, $1.3-2.0=$ stable and $>2.0=$ very stable (Le Bissonnais, 1996).

\subsection{Soil carbon fractions}

Soil samples were analyzed for total organic carbon (TOC) by dry combustion (LECO, St. Joseph, MI). Soil organic fractions were measured by several chemical or physical fractionation methods: coarse and fine particulate organic carbon $\left(\mathrm{POC}_{\mathrm{c}}\right.$ and $\mathrm{POC}_{\mathrm{f}}$, respectively) were determined by particle size fractionation following the procedure of Duval et al. (2013, 2018). Briefly, $50 \mathrm{~g}$ of soil were mixed with $100 \mathrm{~mL}$ of water and dispersed in a reciprocal shaker for $18 \mathrm{~h}$. Then, the dispersed materials were passed through a pair of sieves of $53 \mu \mathrm{m}$ and $105 \mu \mathrm{m}$ of mesh diameter by rinsing several times with water. The material retained on the sieves (sand and particulate organic matter) was dried in an oven at $105{ }^{\circ} \mathrm{C}$ for $24 \mathrm{~h}$ and weighed. The carbon fraction of sizes ranging 53-105 $\mu \mathrm{m}$ and $105-2000 \mu \mathrm{m}$ and representing the $\mathrm{POC}_{\mathrm{f}}$ and $\mathrm{POC}_{c}$, respectively, were measured by dry combustion (LECO, St. Joseph, MI). The carbon content of the fine fraction $(<53 \mu \mathrm{m}, \mathrm{MOC})$ was determined by difference between TOC and $\left(\mathrm{POC}_{\mathrm{c}}+\mathrm{POC}_{\mathrm{f}}\right)$.

Total and soluble carbohydrates ( $\mathrm{CHt}$ and $\mathrm{CHs}$, respectively) were determined employing two different procedures (Puget et al., 1999). $\mathrm{CHt}$ was extracted by acid hydrolysis as follows: $1 \mathrm{~g}$ of air-dried and sieved $\left(<2 \mathrm{~mm}\right.$ ) soil was treated with $10 \mathrm{~mL}$ of $0.5 \mathrm{~mol} \mathrm{~L}^{-1} \mathrm{H}_{2} \mathrm{SO}_{4}$, heated at $80^{\circ} \mathrm{C}$ for $24 \mathrm{~h}$. For $\mathrm{CHs}$ determination, extraction was carried out as follows: $1 \mathrm{~g}$ of air-dried and sieved $(<2 \mathrm{~mm})$ soil was suspended in $10 \mathrm{~mL}$ of distilled water and heated at $80^{\circ} \mathrm{C}$ for $24 \mathrm{~h}$, and hydrolysis was attained by adding $\mathrm{H}_{2} \mathrm{SO}_{4}$ to obtain a $0.5 \mathrm{~mol} \mathrm{~L}^{-1}$ concentration as in the dilute acid hydrolysis procedure. After extraction, each suspension was centrifuged at $4000 \mathrm{rpm}$ for $15 \mathrm{~min}$ (Puget et al., 1999). Carbohydrate contents of the extract were determined by spectrometry using the sulphuric-phenol spectrometric method with glucose as the standard (Dubois et al., 1951).

\subsection{Statistical analyses}

A general linear mixed-effects model was used to determine how aggregates stability tests results $\left(\mathrm{FW}_{10 \mathrm{~s}}, \mathrm{FW}\right.$, Stir, Slow and AS Mean) were influenced by management treatment (three levels: NE, GAP or PAP) and soils order (two levels: Mollisols and Vertisol) as fixed effects and all their interactions. In addition, the model included the influences of subplots nested within plots and nested within soil types as random effects (random intercepts). To further examine the effects of management treatment or soil order on aggregates stability tests, a variance component analysis was used to determine the proportion of the variance of both factors. In this study the management variables were categorized as "dynamic variables" while most of the soil characteristics may be defined as "inherent or static variables". Pearson correlation was used to explain the associations between aggregates stability tests and management variables, SOC fractions and soil physical properties. Those correlations were performed with two data sets corresponding to Mollisols and Vertisol. Linear regressions were built to explain in detail main associations between aggregates stability tests and some variables of interest. Mixed models estimated with lmer function lme4-package (Bates et al., 2011) and variance component analysis where carried out in R environment (R, Development Core Team, 2018). Correlations and linear regression were performed in InfoStat 2014 (Di Rienzo et al., 2011).

\section{Results}

\subsection{Aggregates stability tests performance}

Mollisols presented higher aggregates stability (all tests) compared to Vertisol $(\mathrm{p}<0.001)$ and management treatments showed significant differences in all tests $(\mathrm{p}<0.0001)$. In this model, NE variance heterogeneity was adjusted as it displayed high data dispersion compared to GAP and PAP. AS Mean (FW, Slow and Stir average), showed clear differences in the behavior of management treatments according to soils order (Fig. 1). In the Mollisols, highest aggregates stability was found in $\mathrm{NE}$ treatments followed by GAP and PAP with statistical differences among them (Fig. 1). Following Le Bissonnais (1996) categories, PAP present medium stability, GAP was classified as stable whereas NE present very stable aggregates. The Vertisol showed a different trend compared to the Mollisols. GAP presented the lowest aggregates stability values showing statistical differences only with NE. PAP showed intermediate values with no statistical differences with the other treatments (Fig. 1). NE and PAP were classified as stable and GAP was classified with medium stability (Fig. 1).

For both soil orders, FW presented the lowest values followed by $\mathrm{FW}_{10 \text { s }}$ while Stir test showed the highest aggregates stability in Mollisols (Fig. 1). Aggregates stability was lower in all Vertisol treatments but with less differences between tests. However, $\mathrm{FW}_{10 \mathrm{~s}}$ and $\mathrm{FW}$ tests indicating slaking were lower in the Mollisols compared to the other tests.

As expected, for both soil orders, $\mathrm{FW}_{10 \text { s }}$ presents a high correlation with FW (0.92, p < 0.0001) and also with AS Mean values $(0.96, \mathrm{p}<$ 0.0001 ). On the contrary Stir tests present the lowest correlation coefficients with other tests $\left(\mathrm{FW}_{10 \mathrm{~s}}\right.$ : 0.74; FW: 0.51 Slow: $\left.0.71, \mathrm{p}<0.01\right)$.

To discriminate the effects of inherent and dynamics variables (or 


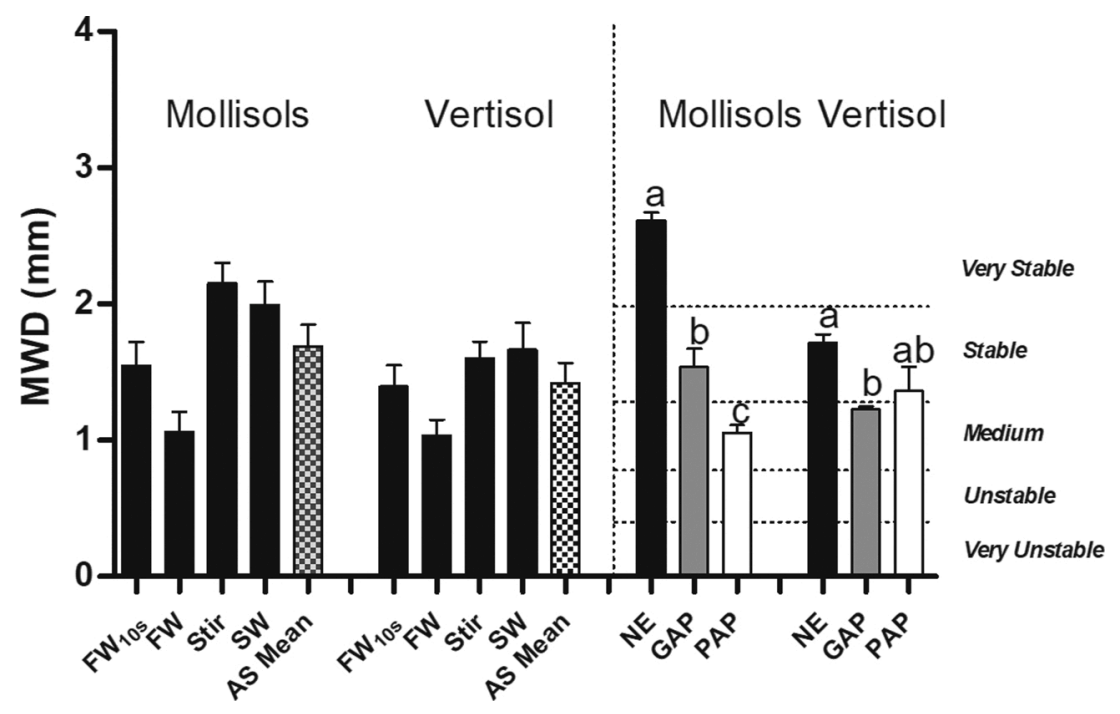

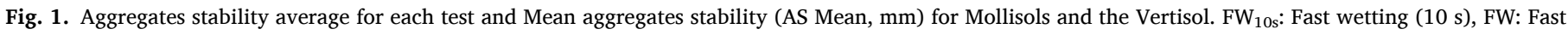

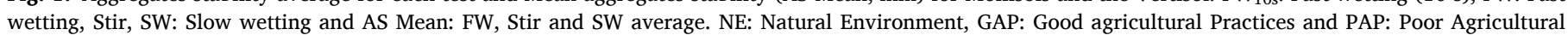
Practices. Dotted lines correspond to Le Bissonnais (1996) classification.

soil type and management factors) a variance components analysis was performed for all tests (Table 2). For Mollisols, $\mathrm{FW}_{10 \text { s }}$ showed the highest variance component for the management factor, followed by FW. Altough SW showed lower proportion of management factor compared to $\mathrm{FW}_{10 \mathrm{~s}}$ and $\mathrm{FW}$, the residual component was lower. Conversely, Stir test showed the highest variance proportion for the soil type and also lower residual values (Table 2). AS Mean presented the higher proportion for mananagement factor and the lowest (close to 0) for soil type. Tests for the Vertisol presented similar ranks. However, AS Mean showed higher proportion of soil type and less management factor. Residuals proportion were similar for both soil orders. Overall, management factor accounted for most proportion of variance.

\subsection{Relationship between aggregates stability and management variables, organic carbon fractions and soil characteristics}

\subsubsection{Aggregates stability tests and management variables}

All agreggates stability tests and AS Mean showed strong and significant correlations with management variables (Table 3 ). The weakest correlations were found with Stir test. Mollisols presented a larger number of significant correlations and with higher determination coefficient (Table 3). For Mollisols, $\mathrm{CI}_{\text {all }}$ presented the highest correlations coefficients whereas Maize/Crops ratio showed the lowest coefficients. $\mathrm{CI}_{\text {agr }}$, which takes into account only the cropping intensification of agricultural managements (GAP and PAP) also presents high and positive correlations with most of the tests. It must be noted that PC1_management, that condense all management variables, showed significant associations with all tests, but lowest coefficient for Stir test. The number of years under NT (NT years) presented a positive correlation with all agreggates stability tests while soybean as only crop in the sequence showed negative associations with agreggates stability. Management variables where maize was included, showed positive correlations although not always with statistical significance.

Particularly, $\mathrm{FW}_{10 \text { s }}$ and FW showed a similar correlation pattern for all management variables with sligh higher correlation coefficient for FW. However the highest correlation coefficient was found between $\mathrm{FW}_{10 \text { s }}$ and $\mathrm{CI}_{\text {all }}(0.93, \mathrm{p}<0.0001)$. Also, SW presented similar correlation coefficient compared to $\mathrm{FW}$ and $\mathrm{FW}_{10 \mathrm{~s}}$. For the Vertisol, only $\mathrm{CI}_{\text {all }}$ correlated with agreggates stability tests (Table 3).

When these correlations were inspected in detail, different behavior according to soil order was found. For all correlations, grouping apart Mollisols from Vertisol improved determination coefficients. Most of the trends in the Vertisol presented opposite slopes or lowest $\mathrm{R}^{2}$ compared to Mollisols (Fig. 2). For instance, PC1_management and Soybean as only crop showed a strong and negative slope for the Mollisols. On the contrary, for the Vertisol, this relationship was not significant and presented a positive slope. For $\mathrm{CI}_{\mathrm{all}}$ and $\mathrm{CI}_{\text {agr }}$ positive and significant linear models were adjusted in the Mollisols. On the contrary, lowest slope and coefficients were found in the Vertisol (Fig. 2).

\subsubsection{Aggregates stability and soil characteristics}

In general, weaker correlations were found between aggregates stability tests and soil characteristics compared to management variables (Table 3). Mollisols showed a higher number of significant correlations, however the determination coefficients in general were low (Table 3). Stir test presented the highest correlations compared to other tests. Stir correlated positively with clay content and CEC and negatively with sand content. Particle density presented a positive relationship with all

Table 2

Variance components (management, soil type and residual) of aggregates stability tests for Mollisols and Vertisol. FW 10 s: Fast wetting (10 s), FW: Fast wetting, Stir, SW: Slow wetting and AS Mean: FW, Stir and SW average.

\begin{tabular}{|c|c|c|c|c|c|c|}
\hline \multirow{3}{*}{$\begin{array}{l}\text { Aggregates stability tests } \\
\text { (Le Bissonnais, 1996) }\end{array}$} & \multicolumn{6}{|c|}{ Variance components (\%) } \\
\hline & \multicolumn{2}{|c|}{ Management } & \multicolumn{2}{|l|}{ Soil Type } & \multicolumn{2}{|l|}{ Residual } \\
\hline & Mollisols & Vertisol & Mollisols & Vertisol & Mollisols & Vertisol \\
\hline $\mathrm{FW}_{10 \mathrm{~s}}$ & 56.0 & 45.4 & 22.4 & 25.8 & 21.6 & 28.9 \\
\hline FW & 43.8 & 50.7 & 39.6 & 23.2 & 16.6 & 26.1 \\
\hline Stir & 28.3 & 23.9 & 56.5 & 30.4 & 15.2 & 45.7 \\
\hline SW & 48.4 & 53.1 & 32.8 & 22.4 & 18.7 & 24.5 \\
\hline AS Mean & 70.0 & 43.8 & 0.1 & 29.2 & 29.9 & 27.0 \\
\hline
\end{tabular}


Table 3

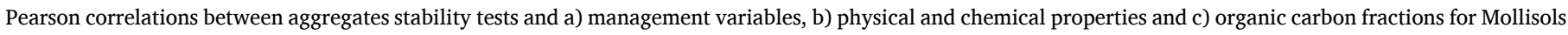

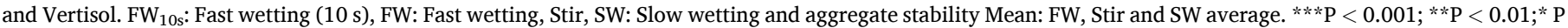
$<0.05$.

\begin{tabular}{|c|c|c|c|c|c|c|c|c|c|c|c|c|c|c|c|c|c|}
\hline & \multicolumn{2}{|c|}{$\mathrm{FW}_{10 \mathrm{~s}}$} & & \multicolumn{2}{|l|}{$\mathrm{FW}$} & & \multicolumn{2}{|l|}{ Stir } & \multicolumn{4}{|c|}{ SW } & \multicolumn{5}{|c|}{ AS Mean } \\
\hline & \multicolumn{2}{|c|}{ Mollisols } & Vertisol & \multicolumn{2}{|l|}{ Mollisols } & Vertisol & \multicolumn{2}{|c|}{ Mollisols } & \multicolumn{2}{|c|}{ Vertisol } & \multicolumn{2}{|c|}{ Mollisols } & Vertisol & \multicolumn{2}{|c|}{ Mollisols } & \multicolumn{2}{|c|}{ Vertisol } \\
\hline \multicolumn{18}{|l|}{ a) Management variables } \\
\hline PC1_management & -0.67 & $* *$ & & -0.65 & $* *$ & & -0.47 & $*$ & & & -0.76 & $* * *$ & & -0.83 & $* * *$ & & \\
\hline $\mathrm{CI}_{\text {all }}$ & 0.93 & $* * *$ & 0.75 & 0.91 & $\begin{array}{l}* * \\
*\end{array}$ & $0.88 \quad * *$ & 0.64 & $* * *$ & & & 0.92 & $* * *$ & $0.89 * *$ & 0.94 & $* * *$ & 0.72 & * \\
\hline $\mathrm{CI}_{\text {agr }}$ & 0.78 & $* *$ & & 0.84 & $\begin{array}{l}* * \\
*\end{array}$ & & 0.17 & & & & 0.81 & $* * *$ & & 0.74 & $* *$ & & \\
\hline Years under NT & 0.62 & $* *$ & & 0.48 & $*$ & & 0.64 & $* * *$ & & & 0.78 & $* * *$ & & 0.90 & $* * *$ & & \\
\hline Soybean/Crops & -0.73 & $* * *$ & & -0.71 & $\begin{array}{l}* * \\
*\end{array}$ & & & & & & -0.79 & $* * *$ & & -0.78 & $* * *$ & & \\
\hline Soybean/Maize & & & & & & & -0.66 & $* *$ & & & -0.51 & $*$ & & -0.74 & $* * *$ & & \\
\hline Maize/Crops & & & & & & & 0.56 & $*$ & & & 0.44 & * & & 0.64 & $* *$ & & \\
\hline \multirow[t]{3}{*}{ Soybean as only crop } & -0.74 & $* * *$ & & -0.72 & $\begin{array}{l}* * \\
*\end{array}$ & & & & & & -0.80 & $* * *$ & & -0.80 & $* * *$ & & \\
\hline & \multicolumn{2}{|c|}{$\mathrm{FW}_{10 \mathrm{~s}}$} & & \multicolumn{2}{|l|}{$\mathrm{FW}$} & & \multicolumn{2}{|l|}{ Stir } & & & \multicolumn{2}{|c|}{ SW } & & \multicolumn{2}{|c|}{ AS Mean } & & \\
\hline & Mollis & & Vertisol & Mollis & & Vertisol & Mollis & & Vertis & & Moll & isols & Vertisol & Molli & & Verti & \\
\hline b)Soil characteristics & & & & & & & & & & & & & & & & & \\
\hline Clay & & & $-0.69 *$ & & & & 0.59 & $* *$ & & & & & & & & & \\
\hline Silt & & & $0.72 *$ & & & & 0.52 & $* *$ & & & & & & & & & \\
\hline Sand & & & & & & & -0.56 & $* *$ & & & & & & & & & \\
\hline Electrical Conductivity & & & & & & & 0.46 & $*$ & & & 0.43 & $*$ & & 0.38 & * & & \\
\hline $\mathrm{pH}$ & & & & & & & & & & & & & & & & & \\
\hline Exchang. $\mathrm{Ca}^{+2}$ & & & & -0.39 & * & & & & & & & & & & & & \\
\hline $\mathrm{Na}^{+} \%$ & & & & 0.41 & $*$ & & -0.47 & $*$ & & & & & & & & & \\
\hline Cation Exchange capacity & & & & & & & 0.65 & $* * *$ & & & & & & & & & \\
\hline Particle density (PD) & 0.59 & $* *$ & & 0.57 & $* *$ & & & & & & 0.52 & $* *$ & & 0.44 & $*$ & & \\
\hline Plastic limit (Pl) & & & & & & & 0.76 & $* * *$ & & & & & & 0.43 & $*$ & & \\
\hline Liquid limit (L1) & & & & & & & 0.86 & $* * *$ & & & & & & 0.54 & $* *$ & & \\
\hline Plasticity index (Pi) & & & & & & & 0.72 & $* * *$ & & & & & & 0.51 & $* *$ & & \\
\hline Clay Activity (CA) & 0.65 & $* * *$ & & 0.55 & $* *$ & & & & & & 0.55 & $* *$ & & 0.52 & $* *$ & & \\
\hline Smectite + interestratified I/S & & & & & & & & & -0.71 & $*$ & & & & & & & \\
\hline c) Organic carbon fractions & & & & & & & & & & & & & & & & & \\
\hline TOC & 0.44 & $*$ & & & & & 0.80 & $* * *$ & & & 0.54 & $* *$ & & 0.64 & $* *$ & & \\
\hline TOC/Clay+Silt) & 0.80 & $* * *$ & & 0.76 & $* * *$ & & 0.31 & $*$ & & & 0.81 & $* * *$ & & 0.73 & $* * *$ & & \\
\hline $\mathrm{POC}_{\mathrm{c}}$ & 0.81 & $* * *$ & & 0.79 & $* * *$ & & 0.47 & $*$ & & & 0.78 & $* * *$ & & 0.79 & $* * *$ & & \\
\hline $\mathrm{POC}_{f}$ & 0.46 & $*$ & & 0.43 & $*$ & & & & & & 0.72 & $* * *$ & & 0.64 & $* * *$ & & \\
\hline MOC & & & & & & & 0.75 & $* * *$ & & & & & & 0.50 & $*$ & & \\
\hline $\mathrm{CH}_{\mathrm{t}}$ & 0.37 & $* *$ & & 0.22 & $*$ & & 0.76 & $* * *$ & 0.80 & $\star \star \star *$ & 0.55 & $* *$ & & 0.58 & $* *$ & 0.46 & * \\
\hline $\mathrm{CH}_{s}$ & 0.79 & $* * *$ & & 0.67 & $* *$ & & 0.62 & $* * *$ & & & 0.79 & $* * *$ & & 0.81 & $* *$ & & \\
\hline
\end{tabular}

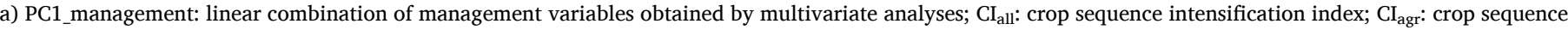

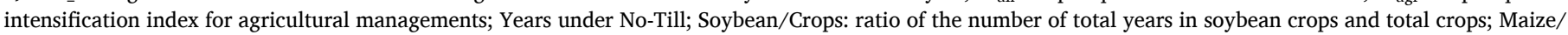

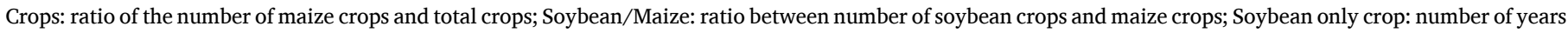

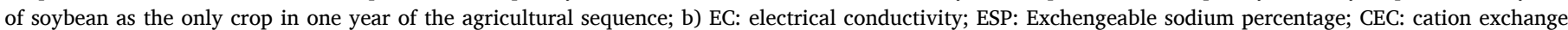

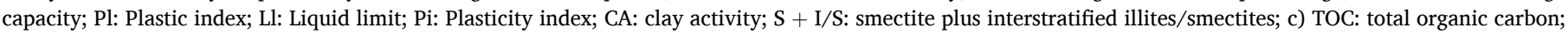

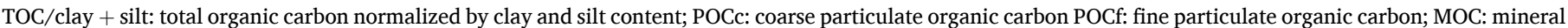
associated organic carbon; CHt: Total carbohydrates and CHs: Soluble carbohydrates.

tests but not with Stir, while clay activity presented a positive relationship with all aggregates stability tests. Many variables as clay content, CEC and liquid limit, was affected by soil order and showed opposite behavior (Fig. 3a-c). For instance, for these three variables the Mollisols showed positive slopes whereas the Vertisol showed negative ones. Contrary, for both soil orders aggregates stability measured by Stir test decreased with higher Smectite + interestratified illite/smectite content (Fig. 3d), although this relationship was more noticeable in the Vertisol.

\subsubsection{Aggregates stability tests and organic carbon fractions}

The effects of organic carbon fractions on the aggregates stability depended on the soil order considered. For the Vertisol only $\mathrm{CH}_{t}$ was correlated with Stir test (Table 3). In turn, for Mollisols, most of the organic carbon fractions showed positive and significant correlations with the aggregates stability tests. Coarse particulate organic fraction
(POCc) presented the highest correlations with all tests (Table 3). On the contrary, MOC showed the lowest correlations coefficients (Table 3). When TOC was related to fine particules (TOC/clay + silt), in most cases this variable increased their effect in all AS tests but Stir (Table 3). Overall, CHs presented higher correlation coefficients compared to $\mathrm{CHt}$ mainly in the Mollisols.

Among aggreggates stability tests, Stir showed the highest correlations coefficients with TOC and $\mathrm{CH}_{\mathrm{t}}$. $\mathrm{FW}_{10 \mathrm{~s}}$ and $\mathrm{FW}$ had similar response and strong correlations with $\mathrm{POC}_{\mathrm{C}}, \mathrm{CHs}$ and $\mathrm{CHt}$; however in all cases $\mathrm{FW}_{10 \text { s }}$ presented stronger relationships for these organic carbon fractions. Some of these correlation were further modeled to show the different behavior between soil orders (Fig. 4a-c). Positive and significant effects of TOC, POCc and CHs on AS Mean were observed only in Mollisols. Conversely, in the Vertisol characterized by higher TOC values, no relationship between these organic carbon fractions and AS Mean were found. For Mollisols the determination coefficients were $\mathrm{CHs}$ 
Mollisols

a

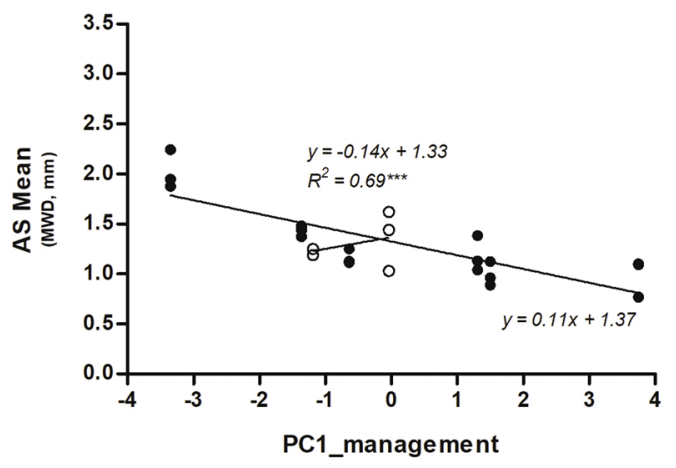

C

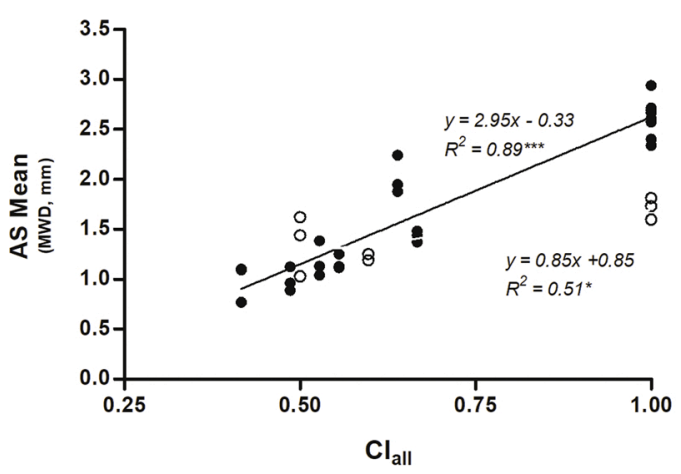

Vertisols

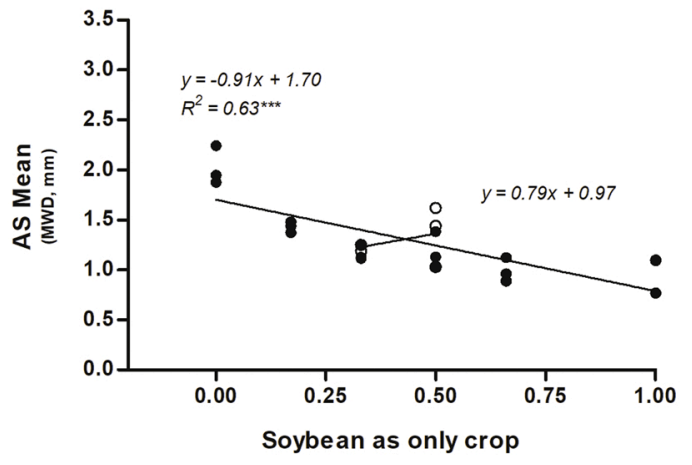

d

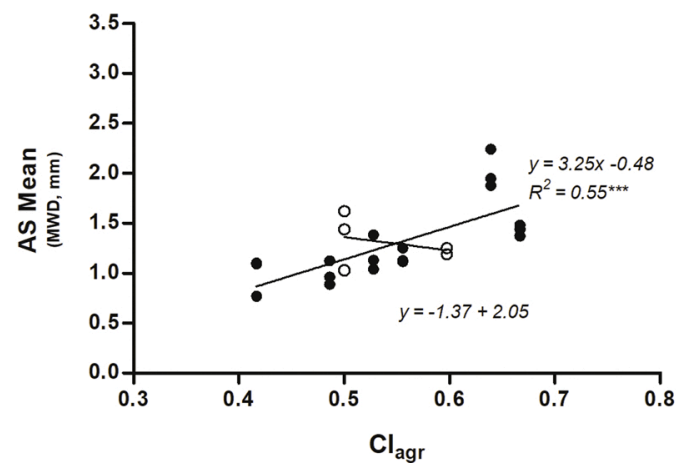

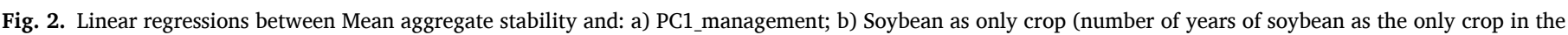

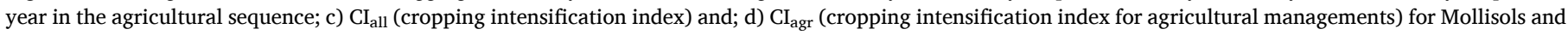
Vertisol. ${ }^{* * *} \mathrm{P}<0.001 ;{ }^{*} \mathrm{P}<0.01 ; * \mathrm{P}<0.05$

$>$ POCc $>$ TOC (Fig. $4 a-c)$.

\section{Discussion}

\subsection{Aggregates stability tests performance}

Aggregate stability has been reported as highly sensitive to changes in agricultural management (Kay and Angers, 2000; Novelli et al., 2013; Castiglioni and Kraemer, 2019). However, studies using different tests to evaluate aggregation mechanisms in soils with contrasting characteristics (i.e. clay content, clay mineralogy) under NT are still scarce. Castiglioni and Kraemer (2019), successfully used Le Bissonnais tests to assess the short-term effect (months) of different cover crops in the Pampa Region of Argentina. Also, Novelli et al. (2013) have used Le Bissonnais tests to evaluate the effects of cropping intensity on aggregates stability in a Mollisol and a Vertisol, finding clear differences between both soils. However, in the present study the effects of soil composition, soil organic fractions and detailed management variables are available to further analyze aggregation mechanisms in different Mollisols and a Vertisol.

In the studied soils, AS Mean ranged from 2.74 in the NE - Haplustoll to $1.03 \mathrm{~mm}$ in the PAP - Argiudoll (Monte Buey series) (Suppl. Fig. 2). Similar results were found in Argentina (2.77 y $0.92 \mathrm{~mm}$ ) for the same soil orders (Mollisol and Vertisol) and for an Alfisol (Gabioud et al., 2011). For coarser soils, Taboada Castro (2011) reported mean weight diameter range from 2.23 to $0.77 \mathrm{~mm}$. AS Mean values of NE treatments, were also in agreement with Gabioud et al. (2011); however, these authors found higher values in the Vertisol (2.77) compared to Molisolls (2.21), while in the present study Mollisols (2.61) showed higher aggregates stability than the Vertisol (2.41). These divergences may be related to differences in the edaphic properties between the subgroups of Mollisols considered in both studies (Typic Mollisols in our case and Aquic Mollisol in Gabioud et al. (2011). These taxonomic differences would correspond to differences in biological activity and the evolution of organic matter, among other properties, generating a decrease of aggregates stability in soils with partially anaerobic conditions.

Most of the tests proposed by Le Bissonnais (1996) as well as the $\mathrm{FW}_{10 \text { s }}$ test (Behrends Kraemer et al., 2012) were here useful to distinguish management treatments due to the high variance proportion attributed to the Management factor and the low proportion regarding soil factor. Besides, all tests showed high correlations with most of management variables (Table 3). Aggregates stability tests with the highest relation to the management factor were those employing more disturbing energy ( $\mathrm{FW}_{10 \text { s }}$ and FW) (Fan et al., 2007; Lado et al., 2004) (Table 2).

Even when both fast wetting tests showed similar variance proportion, $\mathrm{FW}_{10 \mathrm{~s}}$ showed a higher residual component thus suggesting that the number of replicates must be increased to match the discrimination potential of FW. Thus, FW test was the best test to discriminate between management treatments. On the contrary, the variance proportions of Management factor and of Soil type factor were the same in the Stir test.

By analyzing different cropping intensities under NT in different soils of the Pampas, Novelli (2013) and Castiglioni and Kraemer (2019) also found that FW was the main destabilization mechanism of aggregates, followed by SW and Stir tests. This agrees with the findings of Le Bissonnais (1996) and Cosentino and Chenu (2008), who also mentioned the relevance of FW in silty soils. Similarly, Smith et al. (2015) indicates the relevance of slaking in Vertisols. These results suggest that the slake susceptibility of soils studied here may be a main cause of structure degradation. As mentioned by Pinto et al. (2017), even under NT, and 
Mollisols

a

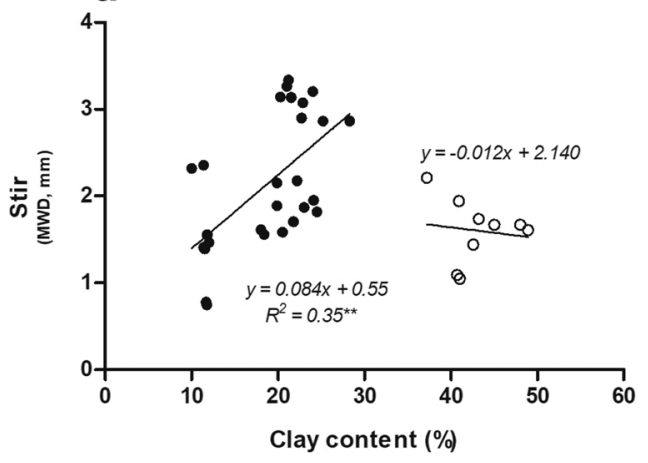

C

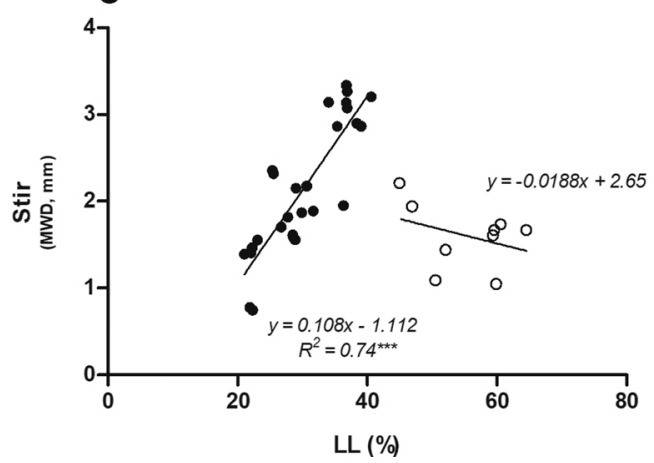

Vertisols

d

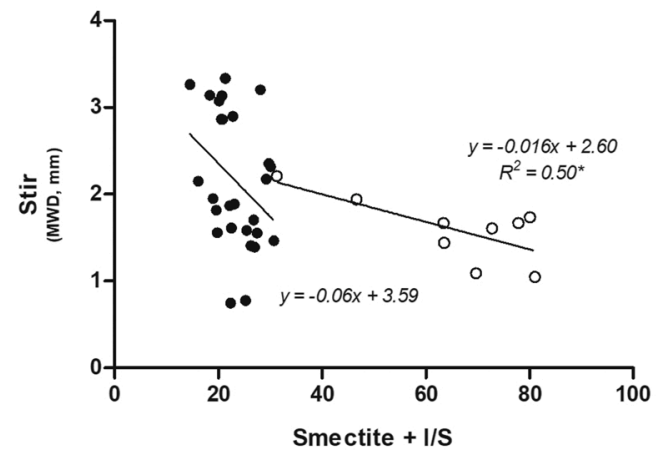

Fig. 3. Linear regressions between Mean aggregate stability and a) CA: Clay activity and $\mathrm{b}) \mathrm{Ll}$ : liquid limit. $* * * \mathrm{P}<0.001 ; * * \mathrm{P}<0.01 ; * \mathrm{P}<0.05$.

due to soil fragility and the absence of a sufficient mulch cover over the years, in some managements (mostly related to PAPs as defined here) soil remains exposed to fast wetting and slaking processes. Besides, in the soils studied here also SW test have showed and important impact on AS. In GAP treatments, crops residue is more abundant decreasing raindrops impact, minimizing the risk of aggregates slaking and surface sealing and therefore lead to a better infiltration rate. Therefore, in plots under NT, different cropping intensities will impact differently on aggregates wetting and on water infiltration. This highlights the relevance of SW and FW tests to assess the stability of soil aggregates.

\subsection{Aggregates tests and management}

As the statistical results of components variance and single correlations with management variables have shown, all aggregates stability tests were close related to changes in agricultural practices. However, when these associations were further inspected, it was evident the contrasting behavior between Mollisols and the Vertisol. In Mollisols, as expected, GAP presented higher AS in all tests compared to PAP. In the Vertisol on the contrary, the impact of management variables on soil structure stabilization was less marked (Table 2, Fig. 1). In this case GAP treatment (i.e with higher cropping intensity and more balanced crop sequence) did not present statistical difference with PAP.

One of the most effective variables to explain AS changes in both soil orders was $\mathrm{CI}_{\text {all }}$ (Table 2, Fig. 2). The same effect of cropping intensity over AS was found by Novelli et al. (2013) in a Mollisol and a Vertisol. Several studies indicate that cropping intensification raise crop yields (Caviglia and Andrade, 2010) and that the higher volume of roots and other plant residues incorporated to soil may enhance biological activity, thus increasing stabilizing compounds in soils (Garcia et al., 2019; Behrends Kraemer et al., 2019) and therefore soil aggregation (Abiven et al., 2007).Other authors suggested that type and quantity of residues may produce different organic matter fractions and thus favor differential aggregates stabilization processes (Angers and Caron, 1998). In fact, Cosentino et al. (2006) showed that the addition of fresh residues on Mollisols have a profound impact on lowering slaking and microcraking (i.e. fast and slow wetting) due to changes in microbial respiration rate and microbial biomass together with increases in pore sizes. Briefly, different cropping intensities resulting in different amounts and frequency of plant residue additions to soil, would modify biological habitats and their activity, impacting on soil aggregation and on pores development processes (Cosentino and Chenu, 2008) and thus leading to differences in water entry.

In the same way, $\mathrm{CI}_{\mathrm{agr}}$, was highly associated with aggregates stability tests suggesting that this soil variable is sound to discriminate agricultural management treatments under NT. The high correlation of $\mathrm{CI}_{\text {all }}$ and $\mathrm{CI}_{\mathrm{agr}}$ with $\mathrm{FW}_{10 \text { s }}$ suggests that the presence of active roots together with higher biological activity promote the occurrence of hydrophobic substances in aggregates (Jaramillo, 2003); these substances produce a decrease of sudden rupture of aggregates due to entrapped air as water permeates more slowly, thus increasing aggregates stability (Hallett and Young, 1999). The effects of agricultural managements on slaking process and hydrophobicity is further studied in Behrends Kraemer et al. (2019) and the formation of crusts and morphological changes of soil aggregates are addressed in Behrends Kraemer et al. (2017) for all Mollisols evaluated here.

Regarding SW tests, Taboada Castro (2011) and Gabioud et al. (2011) mentioned that SW reflects aggregates breakdown due to regular rainfall pattern and high moisture environments, as often occurs after long term cultivation under NT. Comparing conventional tillage with NT over 10 years, Díaz-Zorita et al. (2004) found that NT increases mean weigh diameter of soil aggregates. This is in agreement with the positive relationship and the higher correlation coefficient found here between SW and years under NT, compared to the other aggregates stability tests performed (Table 3). Thus, both slow and fast wetting stability tests appear relevant to evaluate aggregates improvements along with 


\section{Mollisols $\bigcirc$ Vertisols}

a
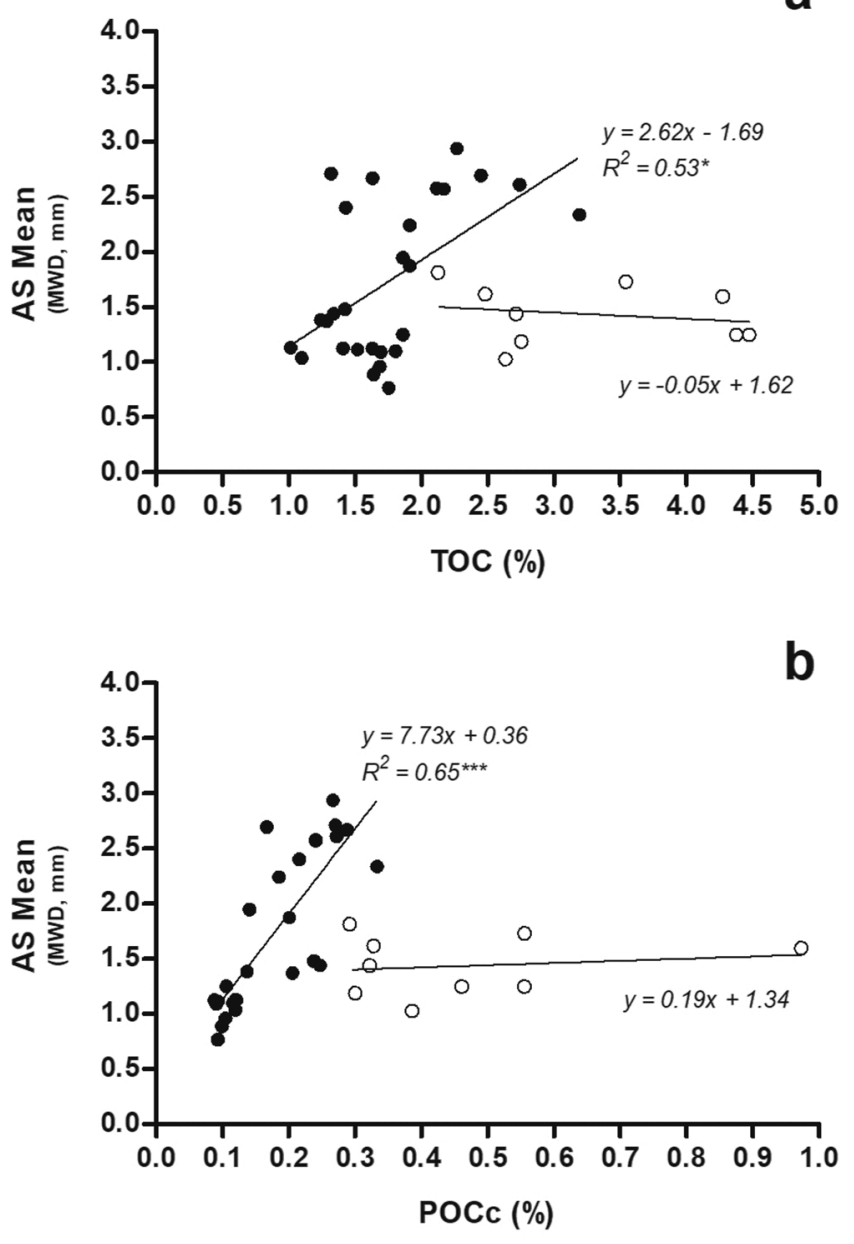

C

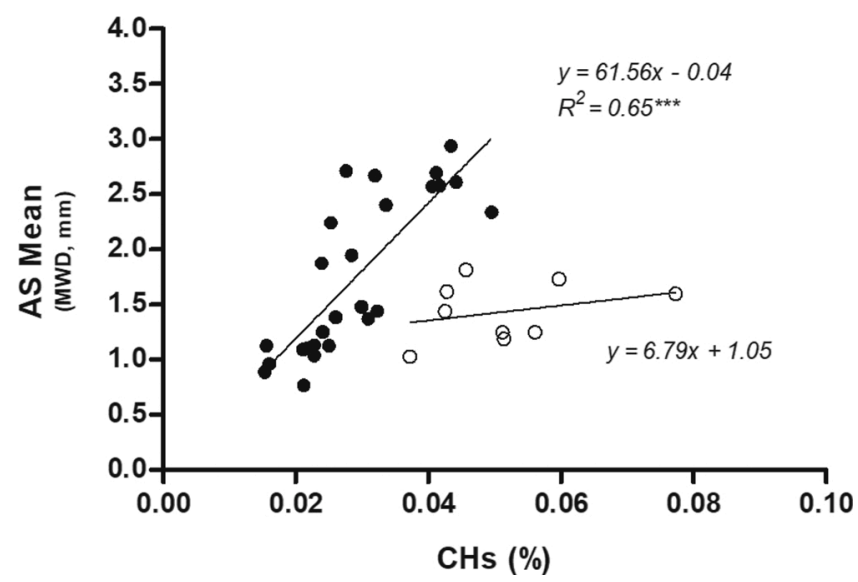

Fig. 4. Linear regressions between Mean aggregates stability and a) TOC: Total organic carbon, b) POCc: Coarse Particulate organic carbon, c) CHs: Soluble carbohydrates for Mollisols and Vertisol. ${ }^{* * *} \mathrm{P}<0.001 ;{ }^{* *} \mathrm{P}<0.01 ;{ }^{*} \mathrm{P}<0.05$.

intensified cropping managements.

Furthermore, clear relationships between high aggregates stability values and more balanced crop sequences (graminea and leguminosae) were also found in this study. The Soybean/crops ratio and soybean as only crop variable, in particular, showed strong and negative tendencies
(Table 4) highlighting the negative effect of soybean cultivation on soil aggregation, even under NT. According to Lynch and Bragg (1985) and Oades (1993), to maintain AS, monocot plants are better than dicot plants due to their greater biomass production (Amézketa, 1999). For Mollisols, Novelli et al. (2013) reported quite similar results with higher AS in more balanced crop sequences. Also, comparing monocultures of soybean and maize after 15 years under NT, Chagas et al. (1995) found that AS in the topsoil was significantly lower in the soybean treatment. Bronick and Lal (2005) mentioned that maize crop residues possess important amount of phenols, a high C:N ratio and high organic carbon and carbohydrates that determines an increment on aggregates stability. Also, mucilages produce by maize roots may directly enhance AS without increasing necessarily soils biological activity (Morel et al., 1991).

On the contrary, the less favorable effect of soybean is related to lower crop residues volume, a lesser roots development and a low biochemical quality leading to poor soil aggregation. However, due to the increment of biological activity that their low C:N ratio promotes, it may counteract those negatives effects of soybean plants (Bronick and Lal, 2005). In this sense, Villamil et al. (2006) found higher AS right after soybean harvesting compared to maize, as the beneficial effect of microbial biomass prevails over the worst residue quality. Nevertheless, in a previous study, after winter crops (graminea) between the soybean/maize crop sequences, higher AS was found due to a higher cropping intensity. All of these findings are also supported in the present work by the positive correlations found between some of the aggregates stability tests and managements variables that include Maize (Table 3).

\subsection{Aggregates stability tests and soil characteristics}

Soils aggregation mechanisms are diverse and the preponderance of each one depends on soil type and its characteristics (Oades, 1993). In the pampean soils, and particularly in the soils evaluated here, free iron and aluminium contents are low (Behrends Kraemer, 2015; Durán et al., 2011). Also, the proportions between exchangeable cations such as $\mathrm{Ca}^{+2}$ and $\mathrm{Na}^{+}$were similar in the different soils and treatments and therefore provides no information to explain differences found in AS (Suppl. Table 1). Overall, all soils have a high silt content (Suppl. Table 1) The Haplustoll has the lower silt content together with the coarser texture. However, sands in these samples correspond to fine sands size and thus physical behavior is analogous to silty samples. On the other hand, an important proportion of the silt fraction in these soils is composed by low density grains (volcanic glasses and phytholits) (Behrends Kraemer, 2015; Osterrieth, 2006). According to Pecorari and Cosentino (1990), this characteristic results in lower mechanical resistance and therefore in lower aggregates stability particularly due to slaking ( $\mathrm{FW}$ and $\mathrm{FW}_{10 \mathrm{~s}}$ ). This behavior was corroborated by the positive relationship between these tests and soil particle density (Table 3), explained in turn by the high proportion of low density silt grains. Besides, this negative effect of silts on aggregates stability affects mostly the Mollisols, due to the strong differences on clay type and content of those soils with the Vertisol, which is also clearly reflected in the contrasting plasticity indexes between both soils orders (Pl, LL and Pi; Suppl. Table 1).

In general, the relationship between soil characteristics and aggregates stability tests was low as evidenced by the low variance component of soil factor and weak correlations between soil principal components (PC1_soil and PC2_soil) and aggregates stability tests. The only test that presented several significant correlations was Stir test. This test evaluates soil cohesion which depends on clay content and other variables related to flocculation of soil particles. In fact, clay content and CEC presented a positive relationship with this test in opposition to sand content and ESP in Mollisols. According to Le Bissonnais (1996) and Taboada Castro (2011) CEC is one of the main variables involved in soil aggregation (Bronick and Lal, 2005). Similarly, AS increased with higher clay activity and liquid limit (Fig. 3).

In Vertisols, the high content of expandable clay plays a fundamental 
role in the aggregation processes (Oades, 1993; Igwe et al., 1999). However, in Mollisols, organic carbon and other dynamic variables are responsible for the degree and changes in soil aggregation and stabilization (Oades, 1993). Therefore, the correlation coefficients of Stir test with intrinsic soil variables were lower than the correlation with management and organic carbon variables. These results were in agreement with Taboada Castro (2011) that reported that the effectiveness of Stir test to discriminate management treatments is higher in coarser soils than in silty soils. It is also to be said that Stir is not considered as an appropriate test in soils under NT due to the fact that this test emulates the direct impact of rain on soils surface, situation that is attenuated in NT due to crop residues (Gabioud et al., 2011). However, in a long term, NT may increase soil cohesion, thus the selection of this test may be adequate to evaluate fragile soils, as silty soils evaluated here (Novelli et al., 2013; Le Bissonnais, 1996).

In the case of the Vertisol, high AS values were expected due to its high smectitic clay content. However, NE treatment showed a lower AS compared to other soils mainly due to the low Stir test values (Fig. 3 Table 3). In this study, Mollisols presented higher AS than the Vertisol (AS Mean 2.61 vs. 2.41, respectively). This could be attributed to their differences in clay composition (Suppl. Table 1). In the case of the Vertisol higher swelling and shrinkage process is expected lowering AS (Igwe et al., 1999). Nevertheless, this same process may also ameliorate soil structure (Denef et al., 2002; Utomo and Dexter, 1982). This was verified in this study as in the Vertisol the minimum AS values were higher than in the other soils and presented lesser AS ranges for all test but SW (Suppl. Table 2).

\subsection{Aggregates stability tests and organic carbon fractions}

The results of this study indicate that the effect of organic carbon fractions on aggregates stability is dependent on the soil order. A significant positive effect of all carbon fractions on AS of Mollisols was observed, whereas in the Vertisol no important effects were detected. Denef et al. (2002) and Novelli et al. (2013) also found different organic carbon effects in relation to soil order and clay mineralogy type. For instance, Denef and Six (2005) reported stronger relationship between organic carbon with illites than with kaolinites.

Several authors highlight the positive effects of organic carbon on AS in moderately weathered soils as Mollisols (Oades, 1993; Six et al., 2004; Álvarez et al., 2014; Novelli et al., 2011) and with about 2\% TOC to achieve stronger effects. (Loveland and Webb, 2003; Smith et al., 2015). In this taxonomic order organic carbon play as a stabilizing agent as indicated by Oades (1993) and Dexter (1988). In fact, in the Mollisols here studied most aggregation lost in the agricultural treatments may be explained by changes in organic carbon fractions, in these soils the threshold for TOC seems to be around $1.5 \%$. In Vertisols, on the contrary, the weak effects of organic carbon effects on aggregates stability, relies on the predominant influence of their clay type and content. For Vertisols, Novelli et al. (2013) and Smith et al. (2015) report a threshold of around $3.5 \%$ TOC at the soils surface $(0-5 \mathrm{~cm})$ to detect effects on AS. However, in this study, higher TOC values did not have any impact on AS (Fig. 4).

In the soils here studied long term effects of cropping intensity are also related to TOC content, in turn showing a strong relationship with Stir test. According to Le Bissonnais (1996), Stir test reflects aggregates cohesion. This force is related to some stable biological bindings but is mostly related to intrinsic soil characteristics (Kay and Angers, 2000). Thus, most recalcitrant organic carbon fractions (MOC and TOC) often bonded to soils clay, showed the highest correlations coefficients with this test. Moreover, Stir relationship with TOC/Clay + Silt becomes weaker suggesting, as mentioned before, that Stir is highly dependent on intrinsic soil characteristics. It must be noted that TOC comprises wide range of carbon fractions and thus may show both dynamics and static behaviour, and therefore this stronger effect on Stir must be understood comparatively.
Several studies state that labile organic fractions (i.e. POC and $\mathrm{CH}$ ) have a marked effect on AS (Tisdall and Oades, 1982; Six et al., 2004) and may have an impact even in Vertisols (McGarry and Malafant, 1987). In the Vertisol studied here, just a single correlation was registered between $\mathrm{CHt}$ and Stir test. In Mollisols instead, the most labile fractions, POCc and CHs, that describe short term shifts in agricultural managements (Duval et al., 2013), showed the highest correlation co-

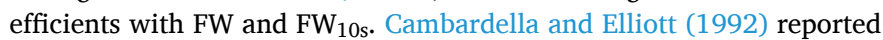
that macroaggregates stability was expressed by the relationship between FW tests and POC fractions. In the Pampean soils here evaluated, high organic carbon content prevented aggregates slaking process. Moreover, the correlations found particularly with $\mathrm{FW}_{10 \text { s }}$ indicate the mechanistic effect of labile fractions on the early slaking process. On the contrary and also supporting these results, the pre-wetting of aggregates in ethanol in Stir tests lowered slaking and differential swelling (Amézketa, 1999); the AS value thus remained high, and lower relationship with labile fractions and Stir compared to $\mathrm{FW}$ and $\mathrm{FW}_{10 \mathrm{~s}}$ were found. These results suggest that those labile organic carbon fractions are sound proxys of aggregates stability due to their relationship with slaking process ( $\mathrm{FW}$ and $\mathrm{FW}_{10 \mathrm{~s}}$ ).

\section{Conclusions}

The stabilization mechanisms of aggregates in the surface horizon of Mollisols with different textures and in a Vertisol from the Pampean Region of Argentina cultivated under no-till with different management practices (GAP and PAP) and in uncultivated plots (NE) were studied in this work. Mollisols showed higher aggregates stability than the Vertisol. Differences on aggregates stability relied on management variables and on organic carbon contents in the Mollisols and on the clay content-clay type characteristics in the Vertisol. In the Mollisols, the labile coarse particulate organic carbon fraction (POCc) determined the shifts on slaking and overall aggregates stability rather than other carbon fractions. Soil aggregates stability was linked mainly to management variables, summarized and best reflected by the cropping intensity index (CI). In both soil orders, more intensive agricultural managements (GAP treatments) resulted in an enhancement of aggregates stability; however, this relationship was stronger in the Mollisols.

In all soils, and particularly under PAP treatments, a high soil fragility related to slaking process was detected. Thus, FW was the best test to discriminate between management treatments and may be recommended for monitoring aggregates stability and soil health in this region. The results obtained in this work allow, on the one hand, to understand the stabilization mechanisms of the structure in the surface horizon of the main Pampas soils and, on the other hand, to highlight the effect of different NT management practices on soils health and on the sustainability of this agricultural system.

\section{Funding}

This work is supported in part by the Argentine Ministry of Science, Technology and Innovation (Grant no. ANPCyT-PAE-2007 n18) and by CONICET (Posdoc grant). Lead author and most of the co-authors are members of the BIOSPAS consortium.

\section{Declaration of Competing Interest}

The authors report no declarations of interest.

\section{Appendix A. Supplementary data}

Supplementary material related to this article can be found, in the online version, at doi:https://doi.org/10.1016/j.still.2020.104901. 


\section{References}

AAPRESID, 2013. Program for Certification in Good Agricultural Practices. Esta repita ta cual en el texto (accessed 11.08.13). http://www.aapresid.org.ar/ac/buenas-practi cas-agricolas/2013/.

Abiven, S., Menasseri, S., Angers, D.A., Leterme, P., 2007. Dynamics of aggregate stability and biological binding agents during decomposition of organic materials. Eur. J. Soil Sci. 58, 239-247. https://doi.org/10.1111/j.1365-2389.2006.00833.x.

Albrecht, A., Rangon, L., Barret, P., 1992. Effets de la matiére organique sur la stabilité structurale et la détachabilite d’un vertisol et d’un ferrisol (Martinique). Chaiers ORSTOM. Séroe Pédol. 27, 121-133.

Álvarez, C., Taboada, M., Perelman, S., Morrás, H., 2014. Topsoil structure in no-tilled soils in the Rolling Pampas, Argentina. Soil Res. https://doi.org/10.1071/SR13281.

Amézketa, E., 1999. Soil aggregate stability: a review. Sustain. Agric. J. 14, 83-150.

Angers, D.A., Caron, J., 1998. Plant-induced changes in soil structure: processes and feedbacks. Biogeochemistry 42, 55-72.

Aparicio, V., Costa, J.L., 2007. Soil quality indicators under continuous cropping systems in the Argentinean Pampas. Soil Tillage Res. 96, 155-165. https://doi.org/10.1016/ j.still.2007.05.006.

Bates, D., Maechler, M., Bolker, B., 2011. lme4: Linear Mixed-Effects Models Using s4 Classes.

Bedano, C., Dominguez, A., 2016. Large-scale agricultural management and soil mesoand macrofauna conservation in the argentine pampas. Sustainability 8, 653. https://doi.org/10.3390/su8070653.

Behrends Kraemer, F., 2015. Doctorado en Ciencias Agropecuarias en la Escuela para Graduados "Alberto Soriano"Facultad de Agronomía, Universidad de Buenos Aires. Beca de Agencia Nacional de Promoción Científica y Tecnológica. SECyT/ Beca Finalización de Doctorado CONICET. Título de la tesis: Influencia de la granulometría y la mineralogía en el comportamiento hidro-físico y estructural en suelos con distinta intensidad de uso y secuencia de cultivos bajo siembra directa, Buenos Aires, Argentina.

Behrends Kraemer, F., Fernández, P.L., Castiglioni, M.G., Morrás, H., 2012. Evaluación del tiempo de inmersión de los agregados en el tratamiento de humedecimiento rápido de la técnica de Le Bissonnais. Actas del XIX Congreso Latinoamericano de la Ciencia del suelo. AACS, Mar del Plata, Argentina.

Behrends Kraemer, F., Chagas, C., Marre, G., Palacín, E., Sanatanatoglia, O., 2013. El desplazamiento de la ganadería por la agricultura en una cuenca representativa de la pampa ondulada. I: efecto sobre el escurrimiento superficial. Cienc. del Suelo 31, 83-92.

Behrends Kraemer, F., Soria, M.A., Castiglioni, M.G., Duval, M., Galantini, J., Morrás, H., 2017. Morpho-structural evaluation of various soils subjected to different use intensity under no-tillage. Soil Tillage Res. 169, 124-137. https://doi.org/10.1016 j.still.2017.01.013.

Behrends Kraemer, F., Chagas, C.I., Ibañez, L., Carfagno, P., Vangeli, S., 2018. Análisis y predicción de la erosividad de las lluvias para el partido de San Pedro (Bs. As.) (Argentina). Ci. Suelo (Argentina) 36 (1), 124-137.

Behrends Kraemer, F., Hallett, P.D., Morrás, H., Garibaldi, L., Cosentino, D., Duval, M., Galantini, J., 2019. Soil stabilisation by water repellency under no-till managemen for soils with contrasting mineralogy and carbon quality. Geoderma 355, 113902. https://doi.org/10.1016/j.geoderma.2019.113902.

Blake, G.R., Hartge, K.H., 1986. Bulk density. In: Klute, A. (Ed.), Methods of Soil Analysis, Part 1. Physical and Minerological Methods. American Society of Agronomy, Madison, pp. 363-376.

Bonel, B., Morrás, H., Bisaro, V., 2005. Estudio de las modificaciones de la microestructura y materia orgánica en un Argiudol bajo distintas condiciones de cultivo y conservación. Cien. Suelo 23 (1), 1-12.

Bronick, C.J., Lal, R., 2005. Soil structure and management: a review. Geoderma 124, 3-22. https://doi.org/10.1016/j.geoderma.2004.03.005.

Calderoli, P.A., Collavino, M.M., Behrends Kraemer, F., Morrás, H.J.M., Aguilar, O.M., 2017. Analysis of nif H-RNA reveals phylotypes related to Geobacter and Cyanobacteria as important functional components of the $\mathrm{N} 2$-fixing community depending on depth and agricultural use of soil. Microbiology Open e00502. https:/ doi.org $/ 10.1002 / \mathrm{mbo3} .502$

Cambardella, C.A., Elliott, E.T., 1992. Particulate soil organic-matter changes across a grassland cultivation sequence. Soil Sci. Soc. Am. J. 56, 777-783. https://doi.org/ 10.2136/sssaj1992.03615995005600030017x.

Cañasveras, J.C., Barrón, V., del Campillo, M.C., Torrent, J., Gómez, J.A., 2010. Estimation of aggregate stability indices in Mediterranean soils by diffuse reflectance spectroscopy. Geoderma 158, 78-84. https://doi.org/10.1016/j. geoderma.2009.09.004

Capriel, P., Beck, T., Borchert, H., Härter, P., 1990. Relationship between soil aliphatic fraction extracted with supercritical hexane, soil microbial biomass, and soil aggregate stability. Soil Sci. Soc. Am. J. 54, 415-420. https://doi.org/10.2136/ sssaj1990.03615995005400020020x.

Castiglioni, M.G., Kraemer, F.B., 2019. Short-Term effect of cover crops on aggregate stability assessed by two techniques. Cienc. del Suelo 37, 298-314.

Caviglia, O.P., Andrade, F.H., 2010. Sustainable intensification of agriculture in the argentinean pampas: capture and use efficiency of environmental resources. Am. J. Plant Sci. Biotechnol. 3, 1-8.

Chagas, C.I., Santanatoglia, O.J., Castiglioni, M.G., Marelli, H.J., 1995. Tillage and cropping effects on selected properties of an Argiudoll in Argentina. Comm. Soil Sci. Plant Anal. 26, 643-655.

Chenu, C., Le Bissonnais, Y., Arrouays, D., 2000. Organic matter influence on clay wettability and soil aggregate stability. Soil Sci. Soc. Am. J. 64, 1479-1486.
Cosentino, D.J., Chenu, C., 2008. Los microorganismos como controladores de la arquitectura del suelo. Fertilidad física de los suelos. Editores: Miguel A. Taboada y Carina R. Alvarez.- $2^{\mathrm{a}}$ ed.- Buenos Aires. Universidad de Buenos Aires, p. 272.

Cosentino, D., Chenu, C., Le Bissonnais, Y., 2006. Aggregate stability and microbial community dynamics under drying-wetting cycles in a silt loam soil. Soil Biol. Biochem. 38, 2053-2062. https://doi.org/10.1016/j.soilbio.2005.12.022.

Denef, K., Six, J., 2005. Clay mineralogy determines the importance of biological versus abiotic processes for macroaggregate formation and stabilization. Eurasian J. Soil Sci. 56, 469-479.

Denef, K., Six, J., Merckx, R., Paustian, K., 2002. Short-term effects of biological and physical forces on aggregate formation in soils with different clay mineralogy. Plant Soil 246, 185-200.

Derpsch, R., Friedrich, T., Kassam, A., Hongwen, L., 2010. Current status of adoption of no-till farming in the world and some of its main benefits. Int. J. Agric. Biol. Eng. 3, 1-25. https://doi.org/10.3965/j.issn.1934-6344.2010.01.001-025.

Derpsch, R., Franzluebbers, A.J., Duiker, S.W., Reicosky, D.C., Koeller, K., Friedrich, T., Sturny, W.G., Sá, J.C.M., Weiss, K., 2014. Why do we need to standardize no-tillage research? Soil Tillage Res. 137, 16-22. https://doi.org/10.1016/j.still.2013.10.002.

Dexter, A.R., 1988. Advances in characterization of soil structure. Soil Till. Res. 11, 199-238.

Di Rienzo, J.A., Casanoves, F., Balzarini, M.G., Gonzalez, L., Tablada, M., Robledo, C.W., 2011. InfoStat versión 2011. Grupo InfoStat. URL. FCA, Universidad Nacional de Córdoba, Argentina. http://www.infostat.com.ar.

Díaz-Zorita, M., Grove, J.H., Murdock, L., Herbek, J., Perfect, E., 2004. Soil structural disturbance effects on crop yields and soil properties in a no-till production system. Agron. J. 96, 1651-1659.

Dubois, M., Gilles, K., Hamilton, J.K., Rebers, P.A., Smith, F., 1951. A colorimetric method for the determination of sugars. Nature 168, 167. https://doi.org/10.1038/ $168167 \mathrm{a} 0$.

Durán, A., Morrás, H., Studdert, G., Liu, X., 2011. Distribution, properties, land use and management of Mollisols in South America. Chinese Geogr. Sci. 21, 511-530. https://doi.org/10.1007/s11769-011-0491-z.

Duval, M.E., Galantini, J.A., Iglesias, J.O., Canelo, S., Martinez, J.M., Wall, L., 2013. Analysis of organic fractions as indicators of soil quality under natural and cultivated systems. Soil Till. Res. 131, 11-19.

Duval, M.E., Galantini, J.A., Martinez, J.M., Limbozzi, F., 2018. Labile soil organic carbon for assessing soil quality: influence of management practices and edaphic conditions. Catena 171, 316-326.

Fan, Y., Lei, T., Shainberg, I., Cai, Q., 2007. Wetting rate and rain depth effects on crust strength and micromorphology. Soil Sci. Soc. Am. J. 72, 1604-1610. https://doi. org/10.2136/sssaj2007.0334.

FAO, 2013. Guidelines of Good Agricultural Practices Developed by the Food and Agricultural Organization of the United Nations (www.fao.org/prods/GAP/index en.htm, last visited August 11, 2016).

Figuerola, E.L.M., Guerrero, L.D., Rosa, S.M., Simonetti, L., Duval, M.E., Galantini, J.A., Bedano, J.C., Wall, L.G., Erijman, L., 2012. Bacterial indicator of agricultural management for soil under no-till crop production. PLoS One 7, 1-12. https://doi. org/10.1371/journal.pone.0051075.

Gabioud, E.A., Wilson, M.G., Sasal, M.C., 2011. Application of the Le Bissonnais method to assess aggregate stability in three soils orders. Cienc. del Suelo 29.

Garcia, L., Damour, G., Gary, C., Follain, S., Le Bissonnais, Y., Metay, A., 2019. Traitbased approach for agroecology: contribution of service crop root traits to explain soil aggregate stability in vineyards. Plant Soil 435. https://doi.org/10.1007/ s11104-018-3874-4.

Hallett, P.D., Young, I.M., 1999. Changes to water repellence of soil aggregates caused by substrate-induced microbial activity. Eur. J. Soil Sci. 50, 35-40. https://doi.org/ 10.1046/j.1365-2389.1999.00214.x.

Hermawan, B., Cameron, K.C., 1993. Structural changes in a silt loam under long term conventional or minimum tillage. Soil Till. Res. 26, 139-150.

Holtzapffel, T., 1985. Les minéraux argileux: préparation, analyse diffractométrique et détermination. Société Géologique du Nord. 12, 136 p.

Igwe, C.A., Akamigbo, F.O.R., Mbagwu, J.S.C., 1999. Chemical and mineralogical properties of soils in southeastern Nigeria in relation to aggregate stability. Geoderma 92, 111-123. https://doi.org/10.1016/S0016-7061(99)00029-4.

Jaramillo, J.D.F., 2003. Efecto de la temperatura de secado del suelo sobre la repelencia al agua en Andisoles bajo cobertura de Pinus patula. Informe de investigación. Universidad Nacional de Colombia, Medellín, 36 p.

Karlen, D.L., Ditzler, C.A., Andrews, S.S., 2003. Soil quality: Why and how? Geoderma 114, 145-156. https://doi.org/10.1016/S0016-7061(03)00039-9.

Kay, B.D., Angers, D.A., 2000. Soil structure. In: Sumner, M. (Ed.), Handbook of Soil Science. CRC Press, Boca Raton, FL, USA, pp. 229-276.

Lado, M., Ben-Hur, M., Shainberg, I., 2004. Soil wetting and texture effects on aggregate stability, seal formation, and Erosion. Soil Sci. Soc. Am. J. 68, 1992-1999. https:// doi.org/10.2136/sssaj2004.1992.

Le Bissonnais, Y., 1996. Aggregate stability and assessment of soil crustability and erodibility: I. Theory and methodology. Eur. J. Soil Sci. 47, 425-437. https://doi. org/10.1111/j.1365-2389.1996.tb01843.x.

Le Bissonnais, Y., Arrouays, D., 1997. Aggregate stability and assessment of soil crustability and erodibility: II. Application to humic loamy soils with various organic carbon contents. Eur. J. Soil Sci. 48, 39-48. https://doi.org/10.1111/j.13652389.1997.tb00183.x.

Loveland, P., Webb, J., 2003. Is there a critical level of organic matter in the agricultural soils of temperate regions: a review. Soil Tillage Res. 70, 1-18. https://doi.org/ 10.1016/S0167-1987(02)00139-3.

Lynch, J.M., Bragg, E., 1985. Microorganisms and soil aggregate stability. Adv. Soil Sci. 2, 133-171. 
McGarry, D., Malafant, K.W.J., 1987. The analysis of volume change in unconfined units of Soil1. Soil Sci. Soc. Am. J. 51, 290. https://doi.org/10.2136/ sssaj1987.03615995005100020005x.

Means, R.E., Parcher, J.V., 1965. Plasticity. Physical Properties of Soils. Prentice-Hall of India Ltd., pp. 68-84

Morel, J.L., Habib, L., Plantureux, S., Guckert, A., 1991. Influence of maize root mucilage on soil aggregate stability. Plant Soil 136, 111-119. https://doi.org/10.1007/ BF02465226.

Morrás, H., Irurtia, C., Ibarlucea, C., Lantin, M., Michelena, R., 2001. Recuperación de suelos pampeanos degradados mediante siembra directa y subsolado. In: Panigatti, Buschiazzo, Marelli (Eds.), Siembra Directa II. Ediciones INTA, Buenos Aires, pp. 263-278.

Morrás, H., Bonel, B., Kraemer, F., Álvarez, C., 2012. Topsoil microstructural models in no-till Pampean Mollisols of Argentina. Morphology and development. In: Proceedings of the 14th International Working Meeting on Soil Micromorphology. Lleida, España (edited in CD).

Nocelli Pac, 2018. Desafíos globales de la productividad agrícola-Por. Santiago Nocelli Pac - Aapresid. https://horizonteadigital.com/desafios-globales-de-la-productivi dad-agricola-por-santiago-nocelli-pac-aapresid/.

Novelli, L.E., Caviglia, O.P., Melchiori, R.J.M., 2011. Impact of soybean cropping frequency on soil carbon storage in Mollisols and Vertisols. Geoderma 167-168, 254-260. https://doi.org/10.1016/j.geoderma.2011.09.015.

Novelli, L.E., Caviglia, O.P., Wilson, M.G., Sasal, M.C., 2013. Land use intensity and cropping sequence effects on aggregate stability and C storage in a Vertisol and a Mollisol. Geoderma 195-196, 260-267. https://doi.org/10.1016/j. geoderma.2012.12.013.

Oades, J.M., 1993. The role of biology in the formation, stabilization and degradation of soil structure. Geoderma 56, 377-400. https://doi.org/10.1016/0016-7061(93) 90123-3.

Osterrieth, M., 2006. Silicofitolitos en suelos, paleosuelos y sedimentos. In: Sanabria, J., Arguello, G. (Eds.), Actas III Congreso Argentino de Cuaternario y Geomorfología. Fac. de Cs. Exact. Fís. y Nat, UNC, Córdoba, I, pp. 351-366.

Pecorari, C., Guerif, J., Stengel, P., 1990. Fitolitos en los suelos pampeanos argentinos: influencia sobre las propiedades físicas determinantes de los mecanismos elementales de la evolución de la estructura. Ci. Suelo (Argentina) 8, 135-141.

Pinto, P., Fernández Long, M.E., Piñeiro, G., 2017. Including cover crops during fallow periods for increasing ecosystem services: is it possible in croplands of Southern South America? Agric. Ecosyst. Environ. 248, 48-57. https://doi.org/10.1016/j. agee.2017.07.028.

Puget, P., Angers, D.A., Chenu, C., 1999. Nature of carbohydrates associated with waterstable aggregates of two cultivated soils. Soil Biol. Biochem. 31, 55-63.

R Core Team, 2018. R: A Language and Environment for Statistical Computing. R foundation for statistical computing, Vienna, Austria. www.r-project.org.

Restovich, S.B., Andriulo, A.E., Portela, S.I., 2012. Introduction of cover crops in maizesoybean rotation of the Humid Pampas: effect on nitrogen and water dynamics. Field Crop Res. 128, 62-70.

Rimski-Korsakov, H., Álvarez, C.R., Lavado, R.S., 2015. Cover crops in the agricultural systems of the Argentine Pampas. J. Soil Water Conserv. 70, 134A-140A. https:// doi.org/10.2489/jswc.70.6.134A.
Rojas, A.C., Conde, A.A., 1985. Estimación del factor R de la Ecuación Universal de Pérdida de Suelo para el centroeste de la República Argentina. Ci. Suelo (Argentina) 3 (1y 2), 85-94.

Rosa, S.M., Behrends Kraemer, F., Soria, M.A., Guerrero, L.D., Morrás, H.J.M., Figuerola, E.L.M., Erijman, L., 2014. The influence of soil properties on denitrifying bacterial communities and denitrification potential in no-till production farms under contrasting management in the Argentinean Pampas. Appl. Soil Ecol. 75, 172-180. https://doi.org/10.1016/j.apsoil.2013.11.012.

Sasal, M.C., Boizard, H., Andriulo, A.E., Wilson, M.G., Léonard, J., 2017. Platy structure development under no-tillage in the northern humid Pampas of Argentina and its impact on runoff. Soil Tillage Res. 173, 33-41. https://doi.org/10.1016/j. still.2016.08.014.

Six, J., Paustian, K., 2014. Aggregate-associated soil organic matter as an ecosystem property and a measurement tool. Soil Biol. Biochem. 68, A4. https://doi.org/ 10.1016/j.soilbio.2013.06.014.

Six, J., Bossuyt, H., Degryze, S., Denef, K., 2004. A history of research on the link between (micro) aggregates, soil biota, and soil organic matter dynamics. Soil Till. Res. 79, 7-31.

Smith, R., Tongway, D., Tighe, M., Reid, N., 2015. When does organic carbon induce aggregate stability in vertosols? Agric. Ecosyst. Environ. 201, 92-100. https://doi. org/10.1016/j.agee.2014.12.002.

Soil Conservation Service, 1972. Soil Survey Laboratory Methods and Procedures for Collecting Soils Samples, Soil Survey, Report 1. United States Department of Agriculture, Washington.

Studdert, G.A., Echeverría, H.E., 2000. Crop rotations and nitrogen fertilization to manage soil organic carbon dynamics. Soil Sci. Soc. Am. J. 64, 1496-1503. https:// doi.org/10.2136/sssaj2000.6441496x.

Taboada, M.A., Barbosa, O.A., Cosentino, D.J., 2008. Null creation of airfilled structural pores by soil cracking and shrinkage in silty loam soils. J. Soil Sci. 173, 130-142.

Taboada Castro, M.M., 2011. Vulnerabilidad estructural en suelos de textura gruesa bajo cultivo y huerta. Terra Latinoam. 21 (1).

Tisdall, J.M., Oades, J.M., 1982. Organic matter and water-stable aggregates in soils. J. Soil Sci. 33, 141-163, https://doi.org/10.1111/j.1365-2389.1982.tb01755.x.

Utomo, W.H., Dexter, A.R., 1982. Changes in soil aggregate water stability induced by wetting and drying cycles in non-saturated soil. Soil Sci. 33, 623-637.

Vermang, J., 2012. Erosion Processes and Physical Quality of Loamy Soils As Affected by Reduced Tillage. PhD Thesis. Ghent University. Faculty of Bioscience Engineering, Ghent, Belgium.

Villamil, M.B., Bollero, G.A., Darmody, R.G., Simmons, F.W., Bullock, D.G., 2006. No-till corn/soybean systems including winter cover crops. Soil Sci. Soc. Am. J. 70, 1936-1944. https://doi.org/10.2136/sssaj2005.0350.

Wall, L.G., 2011. The BIOSPAS consortium: soil biology and agricultural production. In: de Bruijn, F.J. (Ed.), Handbook of Molecular Microbial Ecology I. John Wiley \& Sons, Inc., Hoboken, pp. 299-306.

Wingeyer, A.B., Amado, T.J.C., Pérez-Bidegain, M., Studdert, G.A., Perdomo Varela, C. H., Garcia, F.O., Karlen, D.L., 2015. Soil quality impacts of current South American agricultural practices. Sustainability 7, 2213-2242. https://doi.org/10.3390/ su7022213.

Wischmeier, W.H., Johnson, C.B., Cross, B.V., 1971. A soil erodibility nomograph for farmland and construction sites. J. Soil Water Conserv. 26, 189-193. 